\title{
膀胱癌に対する超選択的動脈栓塞療法
}

$\begin{array}{ccccc} & \text { 長 } & \text { 倉 } & \text { 和 } & \text { 彦 } \\ & \text { 木 } & \text { 村 } & & \text { 哲 } \\ \text { 慶応義塾大学医学部泌尿器科学教室 } & \text { 実 } & \text { 川 } & \text { 正 } & \text { 道 } \\ & \text { 大 } & \text { 沢 } & \text { 吙 } \\ & \text { 主任:田崎寛教授) } & \text { 崎 } & & \text { 寛 }\end{array}$

\section{SUPERSELECTIVE TRANSCATHETER EMBOLIZATION FOR BLADDER CARCINOMAS}

\author{
Kazuhiko Nagakura, Satoru Kimura, Seido Jitsukawa, Akira Ohsawa and \\ Hiroshi Tazaki \\ Department of Urology, School of Medicine, Keio University
}

(Director: Prof. Hiroshi Tazaki)

Preoperative transcatheter embolization of individual vesical artery had been performed on 7 cases of bladder carcinoma followed by variety of resection that enabled the clinical and histological assessments. An end-hole catheter was transfemorally cannulated into a vesical artery concerned and 1-3 ml of gelatine sponge suspension was injected to fill up the arterial tree under fluoroscopic control. Six of the 7 cases had total cystectomy and the remaining one required partial cystectomy 4-15 days after the embolization. The bladder was observed to be edematous and pale over the area nourished by the artery and rather easy to dissect. Estimated blood loss at these total cystectomies was $45 \%$ lower than that in our recent 15 similar cystectomies that were not treated with embolization. Microscopically, formation and phases of organization of emboli and tumor infarction along the vascular trees were observed within the tumorous portion in 4 early stage cases including one case showing a similar change in the muscle layer to a moderate degree. These findings were not seen in 2 cases with advanced carcinoma.

Reviewing literature, transcatheter embolization of hypogastric artery and its branches had been applied for intractable hemorrhage of inoperable bladder tumor and other pelvic tumors, pelvic fracture and A-V malformation of bladder so far. However, the embolization for surgically curable bladder carcinomas has not been documented. We intended a reduction of blood loss in surgery, easy dissection of bladder, discouragement of tumor growth and lessened tumor cell contamination. All but the last of the above have been accomplished. Considering the acceptable degree of side effects, this technique shown in this study is applicable to a wider selection of clinical disorders without sacrificing bladder function in benign diseases as well as malignancies.

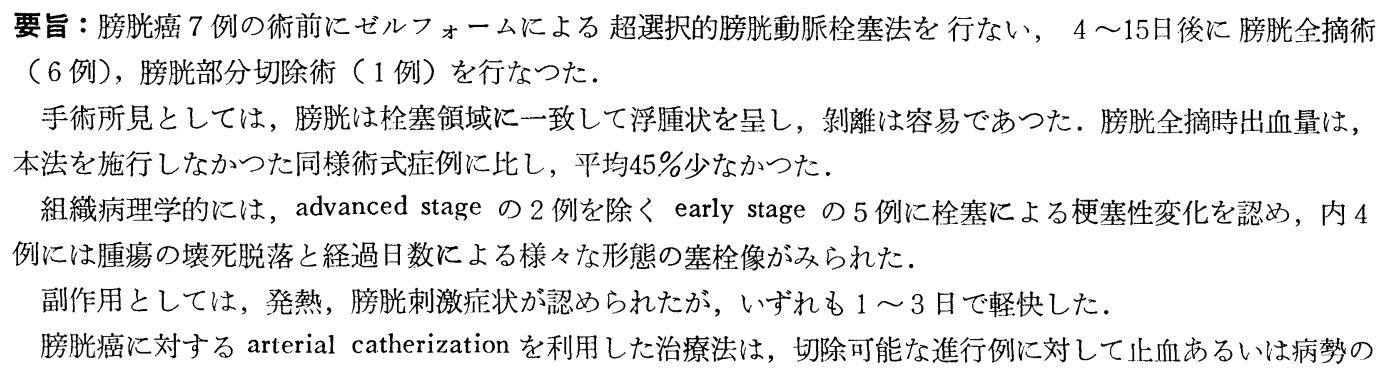


阻止を目的として行なわれているが，手術可能な膀脱癌に対する術前膀胱動脈栓塞は未だ報告されていない．

本法は術中出血量の減少, 病勢の阻止, 腫痬細胞の飛散の防止を当初の目的としたが，ほぼそれれ達するこ とができた。更に，摘出標本より組織学的効果も確認することができた，一方，准行した膀脂癌に対する保存 療法としては，単独の膀胖動脈栓塞のみでは不十分な場合がある事も判明した。

最後に，本法の利点の一つとして膀胱機能を殆んど損わない点が挙げられる。そのため膀胱癌のみならず， 出血を伴う種々の疾患こ対して広く応用が可能であると思われる。

\section{緒 言}

Selective catheterization による動脈造影は，その高 度な診断能力により, 現在, 各科領域に扔いて, 久くこ とのできない重要な検査としての地位を筑いているが, 近年，catheterization の技術を応用した各種物質の動脈 注入による治療が, 脳神経外科, 消化器外科, 婦人科, そして泌尿器科領域に扔いても行なれれる様になつた。

目的と与る臟器の固有動脈にカテーテルを挿入後, 血 管収縮剂，抗腫瘍剂，放射性物質，栓塞物質を注入する ことにより，他臟器に影響を与えることなく，疾患を保 存的に治療しょうとするものである。

栓塞物質を使用した Transcatheter embolization (以 下 TcE と略記) は, 泌尿器科領域に招いても, 腎細胞 癌に対する保存療法あるいは術前処置として, 更に腎動 静脈瘦, 婜出血, 進行した膀胱癌などに対しては, 保存 療法として，ナぐれた効棵が報告されている。

藷者らは從来より䛦断の目的で行なつてきた超選択的
膀胱動脈造影の技術を応用し，1978年 2 月より膀胱全摘 術あるいは膀胱部分切除術の適応となつた膀脱腫瘍 7 症: 例に対し, 術中出血量の減少, 病勢の阻止, 抢よび術中の 腫湟細胞の飛散の防止を目的として術前にゼルフォーム による TcE を行なつた。そして摘出標本より組織学的 な栓塞による治療効果をも確認することができたので, その成績と本法の有用性について, 検討を加光報告する。

\section{方 法}

本法に使用したのは，Mohri ${ }^{16)}$ らの開発した子恕動 脈用カテーテルを基本として, 膀脱動脈用カテーテル (pert 7.2, green, Cook Inc., Bloomington, Indiana) としたもので, 患者の骨盤内血管構造に合わせ, 種々の variationを用意した。

Seldinger 法に従い, カテーテルを右大腿動脈より插 入し，骨盤動脈造影を施行する。高度の血管病変がな く, 膀胱動脈へのカテーテル挿入が可能なことを確認 後, 膀脱動脈用カテーテルと交換する.X線透視下に,

Table 1 Preoperative superselective embolization for bladder carcinoma

\begin{tabular}{|c|c|c|c|c|c|c|c|}
\hline Case & $\begin{array}{l}\text { Age } \\
\& \text { Sex }\end{array}$ & $\begin{array}{l}\text { Site for } \\
\text { embolization }\end{array}$ & $\begin{array}{l}\text { Material for } \\
\text { embolization }\end{array}$ & $\begin{array}{l}\text { Days before } \\
\text { surgery }\end{array}$ & $\begin{array}{l}\text { Surgery } \\
\text { performed }\end{array}$ & $\begin{array}{l}\text { Estimated } \\
\text { blood loss }\end{array}$ & Histological findings \\
\hline 1 & $58 \mathrm{~F}$ & Rt. vesical A. & $\begin{array}{l}\text { Minced gelfoam } \\
\text { with autologous } \\
\text { clot }\end{array}$ & 8 days & $\begin{array}{l}\text { Total } \\
\text { cystectomy }\end{array}$ & $780 \mathrm{ml}$ & $\begin{array}{r}\text { Transitional cell carcinoma } \\
\text { (grade- III, stage-D) }\end{array}$ \\
\hline 2 & $49 \mathrm{M}$ & $\begin{array}{l}\text { Bilateral } \\
\text { vesical Aa. }\end{array}$ & $\begin{array}{l}\text { Minced gelfoam } \\
\text { with autologous } \\
\text { clot }\end{array}$ & 6days & $\begin{array}{l}\text { Total cysto- } \\
\text { prostatectomy }\end{array}$ & $750 \mathrm{ml}$ & $\begin{array}{l}\text { Transitional cell carcinoma } \\
\text { (grade- Il , stage- } \mathrm{B} \text { ) } \\
\text { organization of emboli, tumor } \\
\text { necrosis }\end{array}$ \\
\hline 3 & $75 \mathrm{M}$ & $\begin{array}{l}\text { Bilateral } \\
\text { inferior vesical } \\
\text { Aa. }\end{array}$ & $\begin{array}{l}\text { Minced gelfoam } \\
\text { with autologous } \\
\text { clot }\end{array}$ & 15 days & $\begin{array}{l}\text { Total cysto- } \\
\text { prostatectomy }\end{array}$ & $450 \mathrm{ml}$ & $\begin{array}{l}\text { Transitional cell carcinoma } \\
\text { (grade- II , stage- A) } \\
\text { prostatic hematoma, inflammatory } \\
\text { change of vesical wall }\end{array}$ \\
\hline 4 & $74 \mathrm{M}$ & Rt. vesical A. & Gelfoam powder & 10 days & $\begin{array}{l}\text { Partial } \\
\text { cystectomy }\end{array}$ & $420 \mathrm{ml}$ & $\begin{array}{l}\text { Transitional cell carcinoma } \\
\text { (grade- II , stage- A) } \\
\text { organization of emboli, necrosis of } \\
\text { of main tumor }\end{array}$ \\
\hline 5 & $49 \mathrm{M}$ & Rt. vesical A. & Gelfoam powder & 8days & $\begin{array}{l}\text { Total cysto- } \\
\text { prostatectomy }\end{array}$ & $1440 \mathrm{ml}$ & $\begin{array}{r}\text { Transitional cell carcinoma } \\
(\text { grade-IV, stage-D) }\end{array}$ \\
\hline 6 & $54 \mathrm{M}$ & $\begin{array}{l}\text { Rt. vesical A., } \\
\text { lt. superior \& } \\
\text { inferior vesical } \\
\text { Aa. }\end{array}$ & Gelfoam powder & 4 days & $\begin{array}{l}\text { Total cysto- } \\
\text { prostatectomy }\end{array}$ & $900 \mathrm{ml}$ & $\begin{array}{l}\text { Transitional cell carcinoma } \\
\text { (grade- II , stage- A) } \\
\text { arteritis due to emboli, infarction } \\
\text { of majority of multiple tumors \& } \\
\text { a part of deep musculature }\end{array}$ \\
\hline 7 & $60 \mathrm{M}$ & $\begin{array}{l}\text { Rt. inferior } \\
\text { vesical A }\end{array}$ & Gelfoam powder & 12days & $\begin{array}{l}\text { Total cysto- } \\
\text { prostatectomy }\end{array}$ & $500 \mathrm{ml}$ & $\begin{array}{l}\text { Squamous cell carcinoma } \\
\text { (moderately diffenciated, } \\
\text { stage- A) } \\
\text { organization of emboli, infarction } \\
\text { of } 2 / 3 \text { of tumor }\end{array}$ \\
\hline
\end{tabular}


カテーテルを膀胱動脈に wedge さ好，連続撮影を行な つた後, gelatine sponge 又は powderによる栓塞を行な つた。

栓寒物質には当初，ゼルつォーム (Spongel ${ }^{\circledR}$ 山之内 製薬）の細切片と造影剤と自家血との混和液を使用した が，4例わより粉末ゼルフォーム (Gelfoam ${ }^{\circledR}$ powder, Upjohn Co., Kalamazoo, Michigan) を造影剂 (76\% Urografin $^{\circledR}$ 日本シェーリング) に混和し, paste 状にし たものを使用している。これを透視下にりつくりと逆流 せぬよらに，束た，造影剤が動くことなく，血流が完全 に遮断されるまで約 $1 \sim 3 \mathrm{ml}$ を注入したのち，確認のた わ，栓塞後内腸骨動脈造影を施行した。

雨側膀胱動脈を检塞することを基本としたが，カテー テルが完全に wedge され揚合や，腫瘍が膀胱壁の有 左いずれかに偏在している場合は，一方の膀胱動脈の子 栓塞した。

\section{症例および成績}

膀胱董嫁にて膀胱全摘術, 又は膀胱部分切除の適応と なつた 7 症例に対し, 術前に本法を施行した。症例は男 性 6 名，女性 1 名で，年齢は49歳より75歳杂で，平均60 藏であつた（Table 1)

両側胼胼動脈索栓塞したのは 3 症例で，他の 4 症例 は，右膀胱動脈のみに本法を施行した。症例 1 は，左撙

Fig. 1-a 右内腸骨動脈前枝造影（症例 4）

膀胱右壁に大きな卵円形㓌殿欠損と，その中心上 り放射状に延びる腫煬血管がみられる。

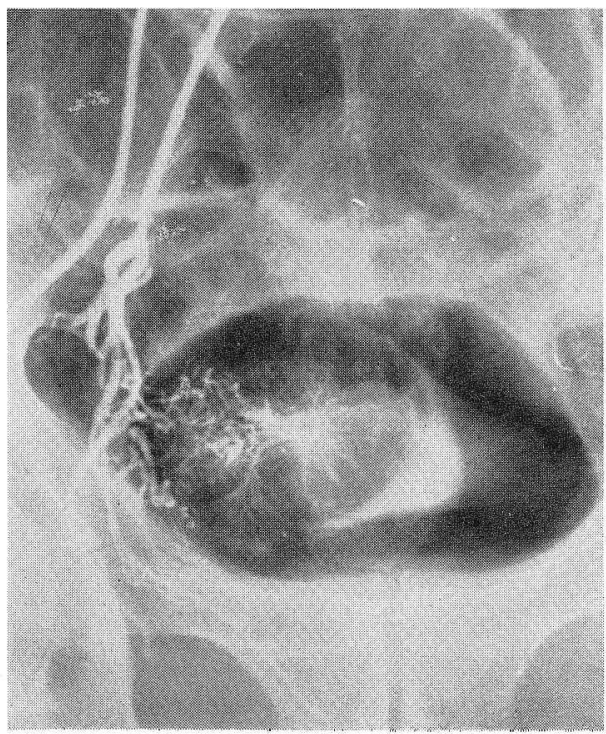

Fig. 1-b 右膀胱動脈栓塞後撮影（症例 4)

塞栓物質と混和した造影剂の膀胱動脈，及び腫瘍 ヘの pooling がみられる。

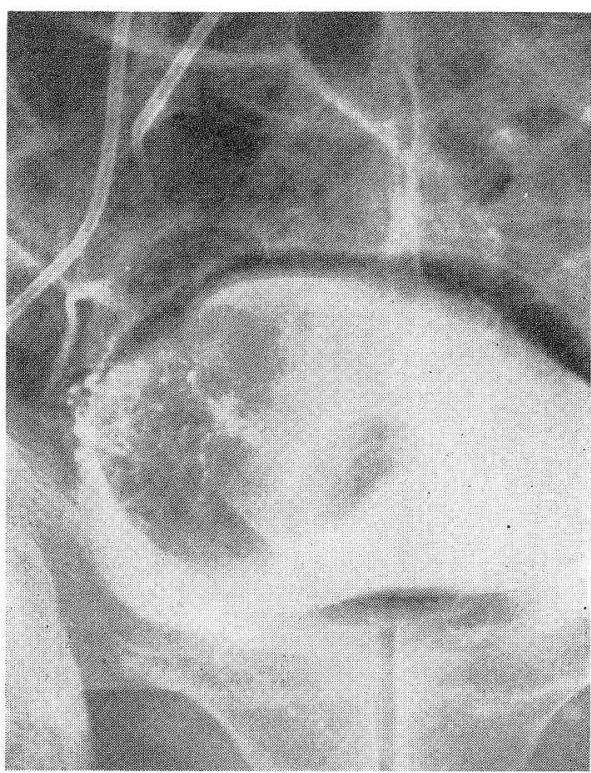

Fig. 1-c 栓塞後内腸骨動脈造影 (症例 4)

Fig. 1-a でみられる腫瘍血管は造影されておらず, 膀胱動脈以外の分枝は，栓塞前之变化を認めない。

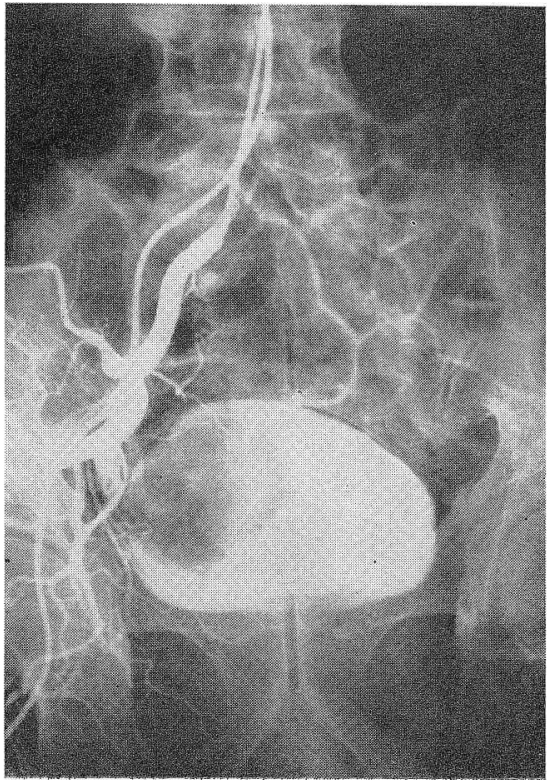


Fig. 2-a 膀胱二重造影 (症例 6)

膀胱の大半を占める多発性腫瘍陰影がみられる。

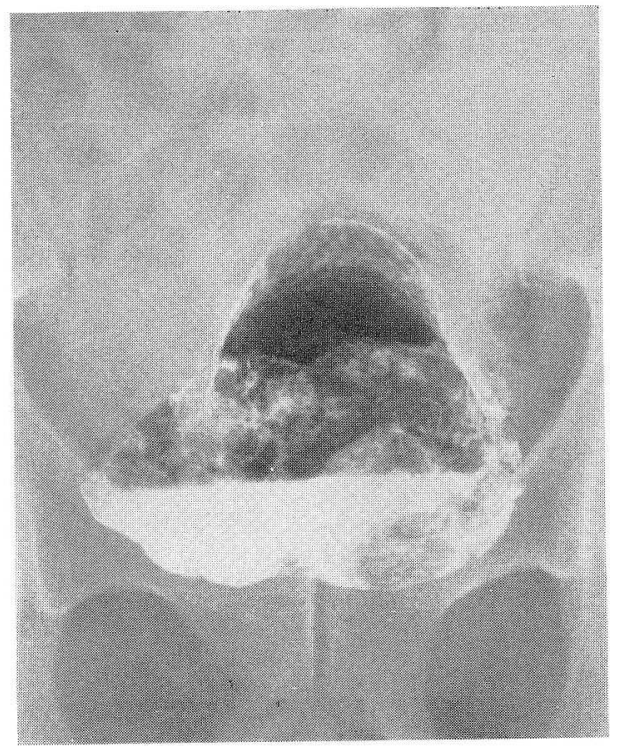

Fig. 2-b 右膀胱動脈造影（症例 6)

膀胱右壁に腫湟院影它認める。

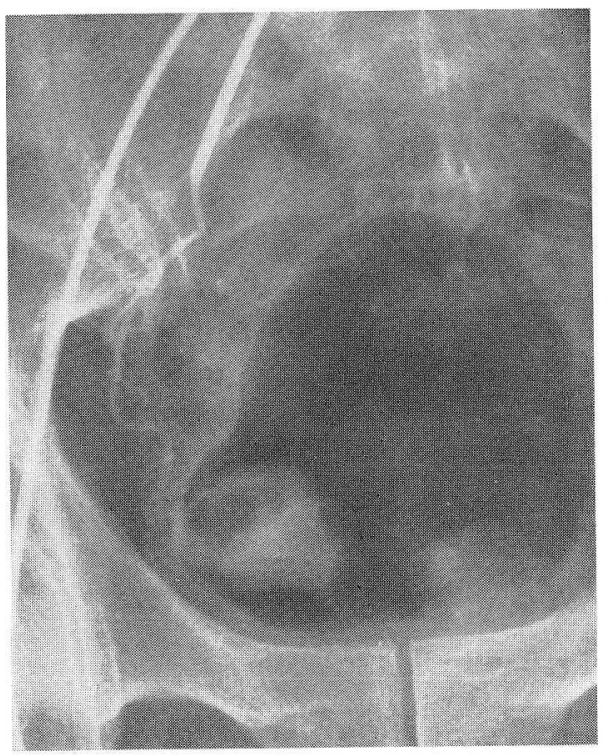

胱動脈にはカテーテルが完全に wedge されぬため中止 した症例であるが，症例 4，5，7は腫瘍が膀胱右壁に のみ存在していると思われたので，片側のみを栓塞し た。
Fig. 2-C 左上膀胱動脈造影 (症例 6) 正常に比して太くかつ分枝の多わい膀胱動脈と, 一部に腫痬による不整な血管がみられる。

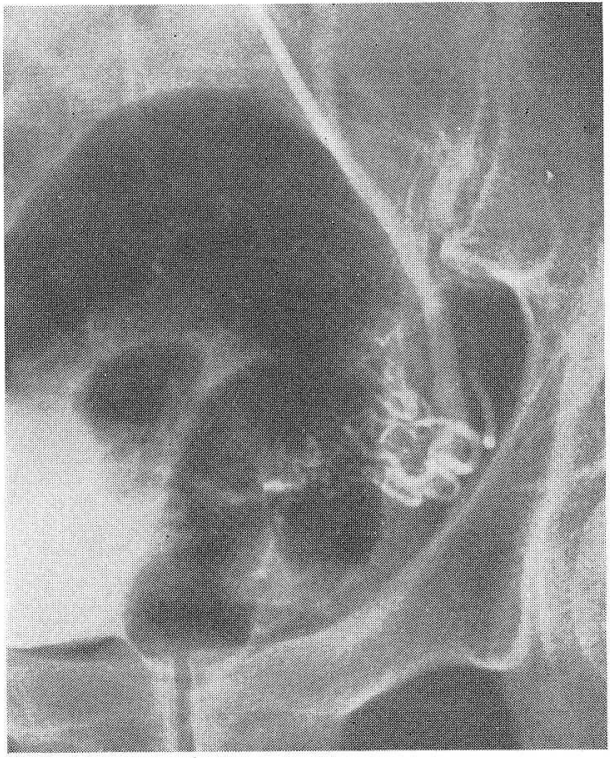

Fig. 2-d 左上, 左下及び右膀胱動脈栓塞後撮影（症 例 6)

ゼルフォームと混和した造影剤の，頂部を除いた 大部分の膀腅壁及び腫痬へのが認められる。

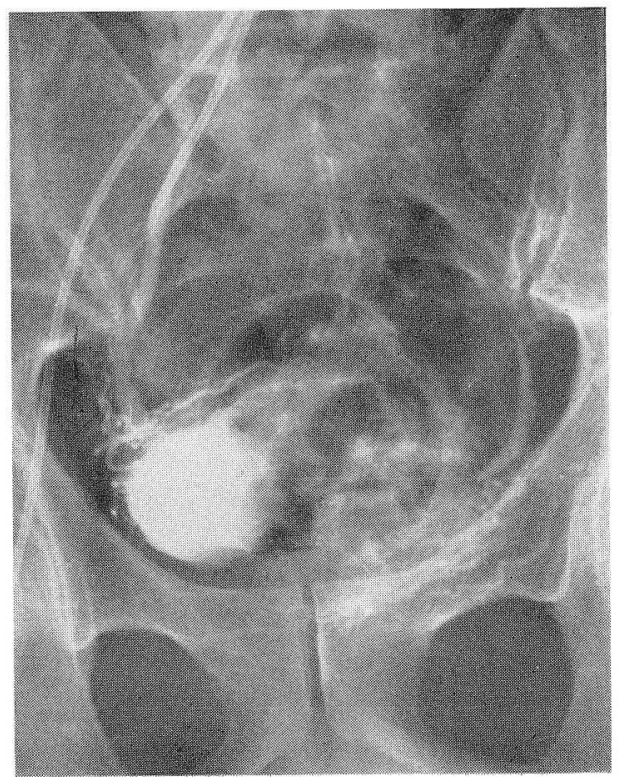


次に代表的症例を挙げる。

症例 4 の内腸骨動脈前枝造影では，膀胱右壁に大きな 腫湯陰影々, 有茎性腫瘍飞特有の腫县中心上り放射状に 延びる腫湯血管がみられる（Fig. 1-a)。更にカテーテ ルを膀胱動脈に插入し, ゼルフオームと造影剤の混和液 約 $2 \mathrm{ml}$ にて栓塞後の撮影では, 腫瘍及び膀胱動脈への 造影剂の pooling がみられ, 内腸骨動脈造影では, 栓塞 した領域一の血流の途絶がみられる (Fig. 1-b，c).

症例 $6 の$ Pneumocontrast cystogram では, 膀胼壁の 大半を占める多発性腫崵陰影が認められる (Fig. 2-a). 右膀胱動脈造影及び左上膀胱動脈造影では, 多発性の

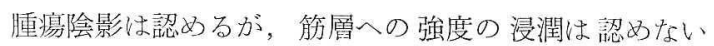
(Fig. 2-b，c)．3本の膀胱動脈を栓塞後の撮影では, 膀 胱及び㣫瘍全体への造影剤の pooling がみられる (Fig. $2 \mathrm{~d})$.

本法施行による副作用と思われるものは，6 例に発熱 や膀踏刺激症状が認められたが，いずれの症例曲軽微 で, 1 日〜3日で添济正常に復している.

本法は術前症例飞施行したため, 栓塞物質の逆流や漏

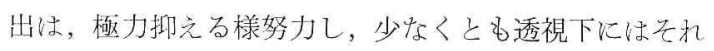
ら老認めることはなく，又，塞检の飛散とよると思われ る症状は諗めなからた。

本法施行後，1例に血尿の消失を認めたが，すでに尿 路変更党行なつていた症例 1 老除く 5 例は栓塞前上り肉 眼的血尿はなく, 栓塞後も变化はなからた。

本法施行後, BUN, クレアチニン, トランスアミナー ゼ, IDH などの変動を観察したが, 症例 5 飞 LDH, 特よびトランスアミナーゼの軽度上昇をみのみであつ た。

手術は本法施行 4 日～15日後（平均 9 日）に行なつ た。膀脱全摘術 6 例, 及び膀胱部分切除術 1 例で, 部分 切除の 1 例は, 右尿管口直上に発生した大きな有茎性䭪 瘍であつた。他の6 例は, 生検にて悪性度が高いこと, あるいは多発性腫揚のため切除困難等の理由により全摘 術の適応となつた。

術中所見としては, 栓塞した領域に一致して, 膀胱周 团浮腫状で色調は荅白であり, 膀脱の刑離は容易であ つた。 また, 症例 $3 ， 7$ では通常最も出血しやすい前 立腺周目及び尿道前立腺移行部よりの出血が非常に少な かつた。

術中出血量は，全摘手術を施行した 6 症例の平均 803 $\mathrm{mI}$ で, 本法を施行しなからた同様術式，15症例の平均 約1,473，より約45\%少なかつた (Table 2)。
Table 2 Comparison of estimated blood loss in total cistectomy with and without preoperative TcE.

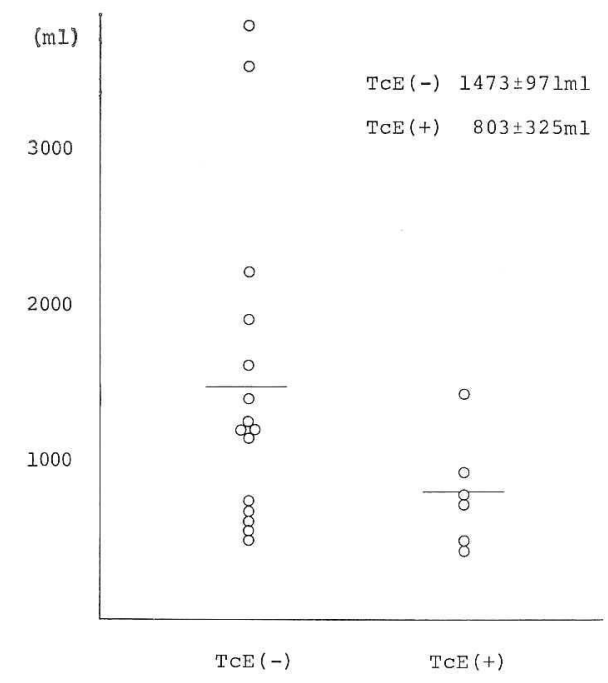

Fig. 3 摘出標本 (症例 4)

左は切除された膀胱壁で, 一部の正常粘膜を除く 大部分が腫堭付着部であり, 外科ソンンデは尿管を通 部じする。

腫韵は直径約 $4 \mathrm{~cm}$ で, 術中すでに膀胱内に脱落 “遊離していた。

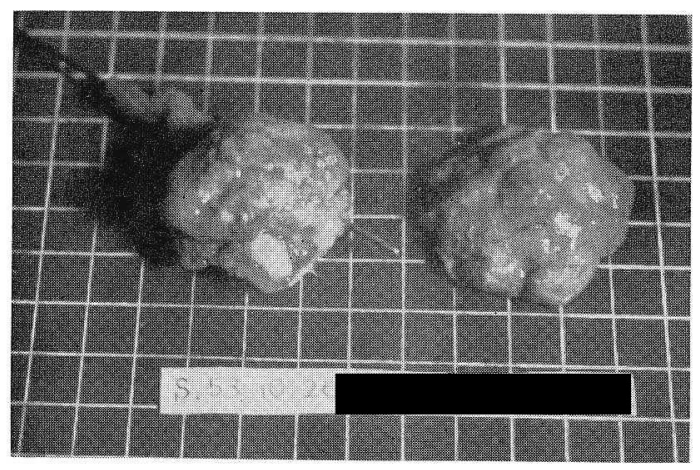

病理組織学的には, 扁平上皮癌 1 例, 移行上皮癌 6 例 で, ゼルフォームまたは粉末ゼルフォームによる明らか な塞栓形成之腫瘍壊死のみられたのは, 症例 2,4, 6, 7 の 4 例であつた。特に症例 4 では, 主腫瘍の完全 な壞死脱落がみられ，近接した部位の小さな娘腫怕以外 の䏦瘍組織の遺残はなかつた (Fig. 3). 形成された塞 栓の形態をみると, 症例 2 では塞恮は一部血管内腔と癒 合し，リンパ球浸閵，フィブリン析出と，ところどころ 
Fig. 4 栓塞 8 日後の組織所見（症例 2 )

塞栓の血管内腔との癒合, リンパ球浸潤, フィブリン析出及び空胞化した中にゼ ルフォームの線維がみられる。

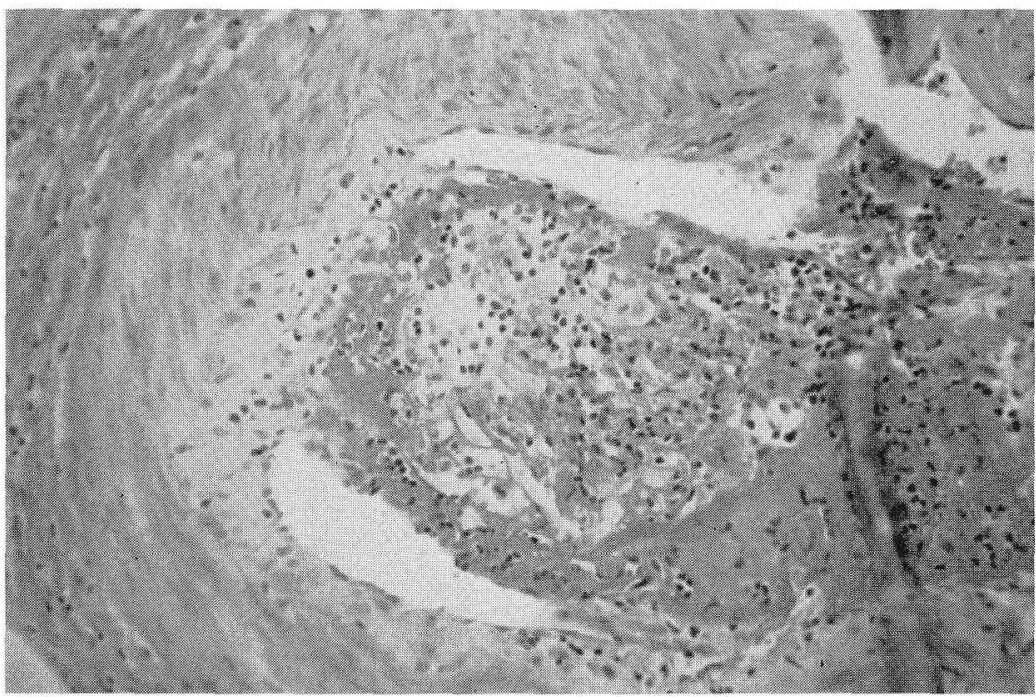

Fig.5 栓塞10日後の組織所見（症例 4)

フィブリンの析出と共に, 線維芽細胞增殖による栓塞の器質化がみられる。

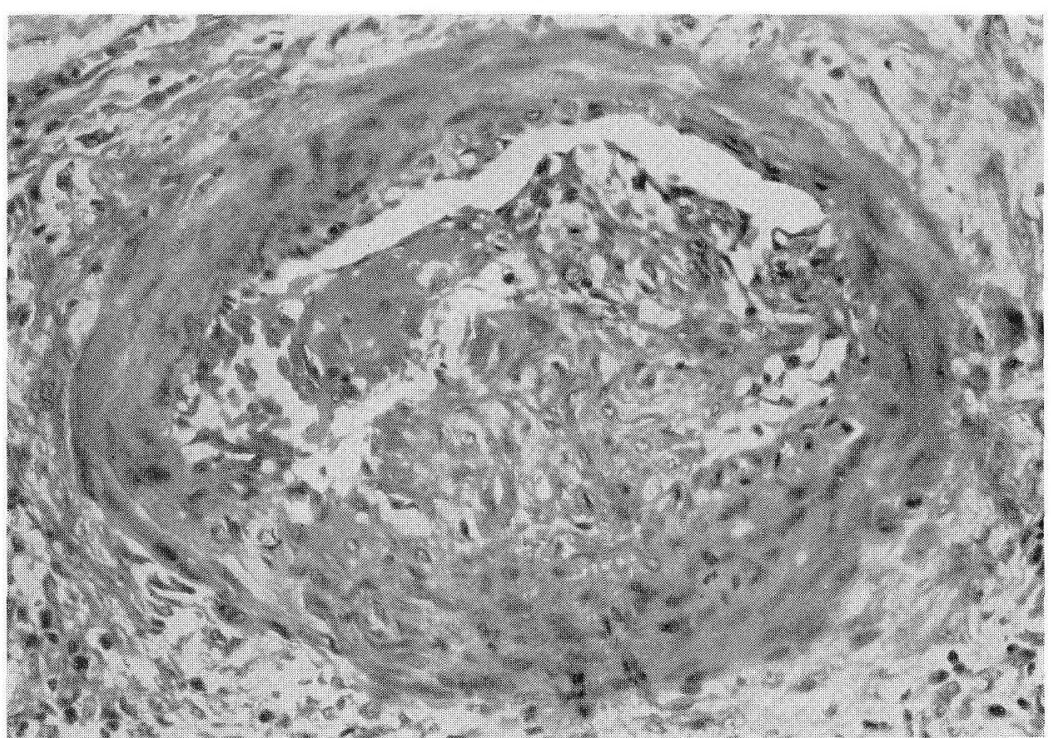

空胞化した中にビルフォームが認められた (Fig. 4). 症例 4 では塞栓が形成された血管空は狭細で, フィプリ ンの析出, 線維芽細胞の增殖による器質化がみられ, 症 例 6 では血管脘内はフィブリンとゼルフォームで栓塞さ れ，周囲には炎症性細胞浸潤と溒死が办られた（Fig，
5，6)，正常な筋層に拈ける梗塞性変化は，症例 6 に打

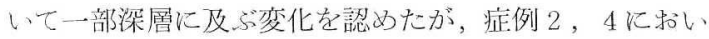
ては浅層の筋層のみにごく軽微な変化を認めたのみであ つた. Stage D の 2 症例では, 標本中に腫瘍壊死部分を 認めた日のの，明らかな塞栓形成は認めら机式， TcE 
Fig. 6 栓塞 4 日後の組織所見（症例 6)

ゼルフォームによる塞栓形成と，血管周囲には炎症性細胞浸潤及び壊死がみられ る。

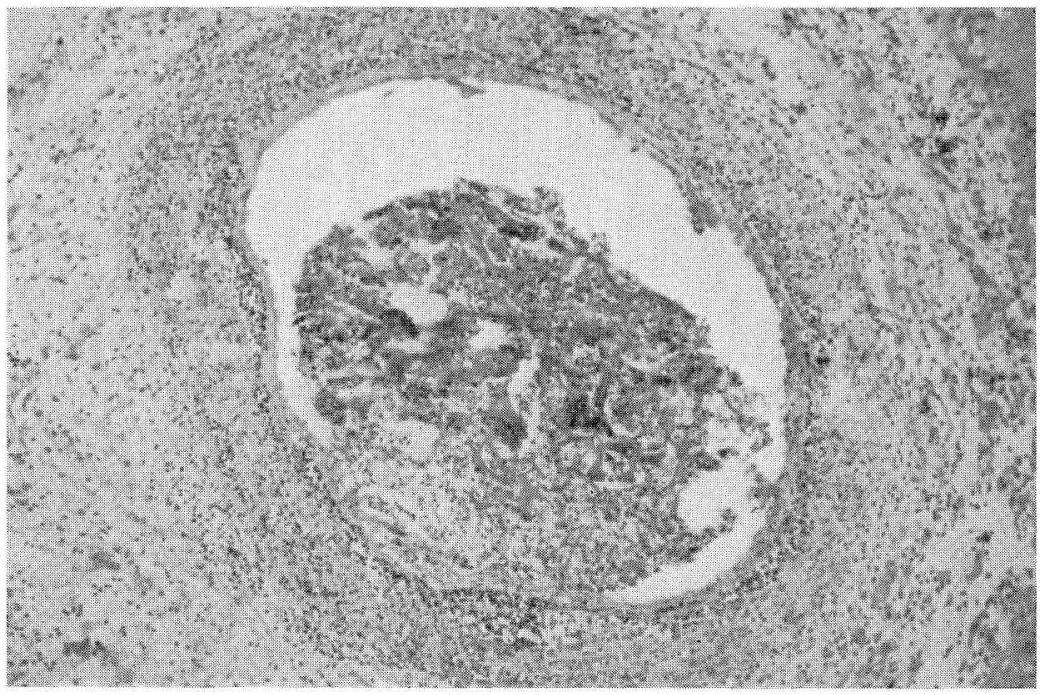

による効果であるかどらか判定は困難であつた。

\section{考察}

泌尿器科領域に扣ける動脈栓塞療法は1969年 Lalli ら の郜床報告がみられる。これらの多くは腎細胞癌 ${ }^{23) 68) ~}$

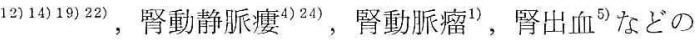
腎疾患に対する TCE であるが，いずれもほぽ満足す ベさ効果が認められている。これらの報告によると, 現 在，腎に対する TCE は，進行した腎細胞癌に対する保 存療法として，あるいは手術手技を容易にすることや， 手術適応の拡大を目的とした術前処理として，更に腎動 静脈瘦, 腎動脈瘤, 腎出血に対しては新しい治療法とし て諗められつつある。

一方，骨盤内の動脈栓塞療法は，主に骨盤骨折 ${ }^{1320}$, 進行した子管癌 ${ }^{715)}$ や膀胱癌 ${ }^{1121)}$ などに対する保存的療 法としての報告が散見される。膀胱腫瘍に対するものと 乙ては，1971年，E.K. Lang ${ }^{10\}}$ が, radioactive pellets を直視下に膀胱動脈に插入したものが，最初の報告です ると思われる。以来, 進行した膀胱㿋の処置困難な出血 に対する保存療法として，内腸骨動脈あるいはとの分枝 への TcE へ上発展して来て物り。比た止血效果が 挙げられている ${ }^{11) 21)}$. 更に最近は, 膀胱動静脈瘦に対す

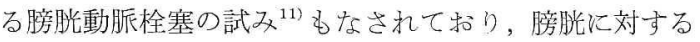
$\mathrm{TcE}$ も徐々にその適応䈟围を広げつつある。乙かしな
がら，膀胱に対する術前 TcE を行ない，その組織学的 効果孛確認したとの報告はみられていない.

進行した膀胱腫瘍では，その栄責血管が膀胱動脈のみ であることは少なく，症例 $1 ， 5$ の加く，単独の膀胱動 脈に対する TcE では不十分な場合もあるであるら。そ のため，この様な症例に対する保存的 TcE としては， 膀腅動脈上り内腸骨動脈に対寸るものの方が確実であ り，かつ容易で㐫るとも推察される。しかしながら，他 臓器に影響を与学ることなく, な扣かつ膀胱機能を保存 しよらとする場合や，膀胱手術の術前に施行する場合 に，内腸骨動脈を栓塞すると，膀胱周囲にまで壞死，線 維化などを打こし，かえつて摘出困難となり，また中空 臓器であるため, 膀胱破裂を起こす危険性も十分に考え られる、著者らは、この様な症例には，膀胱動脈のみ毒 栓塞することでこれらの障害や危険性は解消できると考 总，本法を膀胱癌の術前に施行した。

内腸骨動脈尔るいは膀胱動脈へのカテーテル插入法之 しては，鎖骨下動脈，腕頭動脈，又は反対側の大腿動脈 よりの方法を推奖する報告もあるが ${ }^{11) 15) 201}$, 著者らは， 通常の腹部血管造影と同様に右大腿動脈より行なつてい, る。骨盤動脈造影を行ない, 高度の血管病変を伴なつて いることが判明した2例には本法は行なわ扎なからた が，それ以外の症例は，目的の膀胱動脈へのカテーテル 挿入は可能であつた。 
栓塞物質は，当初ゼルフオームの緗切片と自家血を造 影剂に混和したものであつたが，4例かより更に微細な 血管への栓塞を期待し粉末ゼルフォ一ムを造影剤に混 利，paste 状にしたものに変更しており，良好な結果が 得られている。現在までに使用されている栓塞物質とし ては, 著者らも使用したゼルンォ一ムの他, 種々の物質 が，それぞれ目的に応じて使用されている。本法に扰い こは，対象となる膀胱動脈自体，非常に細い血管であ り, 又膀胱の血管構造上:, 粘膜ト及び腫揚内の微細な動 脈まで怜塞しなければその効果が期待できないと思われ るため，粉末ゼルフォーム，市るいはそれに近似与る微 細な䊉状または線維状の物質が推桨されると考える。

ゼルフォームによる栓塞の再開通の時期については様

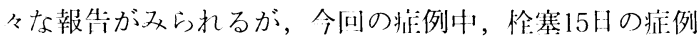
では明らかな寒栓形成を認めなかつたものの，栓塞栓形

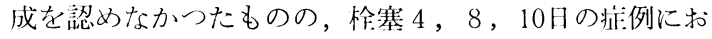
いては, 血管炎からンィブリン析出, 更には線維芽細胞 増殖による塞柃の器質化への過程がみられている。 high stage の 2 例には明らかな塞怜形成を認めることができ なかつたが，その理由としては栓塞が片側膀胱動脈にの 又行なわれたこと，栄荃血管が膀胱動脈のみではない可 能性が高いこと，などが举げられる。特に症例 1 では, 動脈造影上，腫瘍は子宮動脈よりの血液供給も受けてお り，本法は腫瘍への血流を減少させることによる出血量 の減少を目的として行なわれた。

本法による副作用はいずれも軽微であり，過去の報告 にみられるよらな末梢動脈栓塞などの重範な合併据: ${ }^{32}$ 25) は浔められなかつた。本来，内腸骨動脈に対しても栓塞 は可能であり，又，本法に使用される塞栓物質が極く少 量であるので，その様な合併拉妾起こす危険性はほ上ん どないと思われる。

著者らが目的としたのは，術前処置として術中出向量 の減少, mass reduction を主体とした病勢の阻此, 腄湯 細胞の術中飛散の防止を, 膀胱周囲組織に影響を残すこ となく行ならことであつた。そしてそれらの目的は，ほ ぼ達成することができたと考えられ，術前処置としての 本法の有用性が㴓められたが，腎細胞癌に対する TcE の様に手術適応の应大といら意味では今後の検討を要与 るであろう。本来, 摘出困難な膀胱癌は, 直接浸潤を伴 ならものであり，たとえ腫湯が壊死しても，腎癌の様に 中心性に縮少化するとは考えられない，そのため，膀胱 摘出は容易にしえても，腫瘍の完全除去を可能にするか 否かは, 現在の所不明である。しかしながらこの様な進
行癌に対しても，止血や mass reductionを主体とした 保存療法としてであれば，本法は有用な治療法となりら るであろら. 又, 経動脈的な化学療法剤の注入に拈いて もここれで行なわれていた内腸骨動脈への注入 ${ }^{17) 18) に ~}$ 比べ，膀脱動脈へのの直接注入はより一層確実な效果が 期待できる.

動脈栓塞による货疫学的効果については, 腎紐胞嵒に 刘して若下の城告 ${ }^{2}$ がなされているものの，明らかな効 果は認められておらず未だ不明な点が多い、本法におい ても, 今问の経験では, 免疫学的活性度の上昇は認めら れて扝らず，今後の課題の一つである.

本法の最大の利点は，4〜15日と短期の観察であつた が，膀胱機能に大きな障害を残寸ことなく行ない得た事 であると思われる．組織学的にも 3 本の膀胱動脈を栓塞 した症例 6 に，一部深部筋層に及ぶ梗塞を認めたのみ で，他の怔例の筋層には殆ど変化を認めていない。これ によつて本法施行後も, 膀胱が保存され得ることが明ら かになつた。

加漛ら ${ }^{8)} も$ 述べているよらに，腎はその解剖学的特徵 から TcE に非常に適した臓器であるのに比し，膀胱は IfIL管構造，中空で動的機能を持つ臓器であること，又， 到用組織と連続性のあることなどの理由により，必ずし も $\mathrm{TcE}$ に適した臓器でないことは否めない。しかしな がらこの様な解椡学的障害も，技術的な收良で解決され るものと思われ，一層の発展が期待される。

今後は症例を重ね, 当初の目的の他, 腫陽に対する免 疫学的側洏や，良性疾患への応用についてて検討を加え， その有效性を追求する予定である。

\section{結語}

1. 膀胱癌 7 症例の術前にゼルフォームによる膀胱動 脈栓塞を行なつた。

2. 術中，膀胱洜離は容易であり，出血量は本法を施 行しなかつた同様術式症例に比べ平均約 $45 \%$ 少なから た。

3. 病理組織学的には, early stage の4例に塞栓形 成, 腫癔壊死が垫められ，内 1 例には一部深部筋層に及 ぶ梗塞を認めた。

4. 副作用としては, 一過性の発熱, 膀胱刺激症状が 㤎められたが，共に重篤なものではなかつた。

5. 本法は膀胼癌の術前処置としてのみではなく, 膀 脱癌あるいは良性疾患に対する膀胱保存療法として，応 用可能であることが判明した。

本稿の要旨は, 1978年 9 月第43回日本泌尿器科学会東 
部連合総会, 1979年 4 月第67回日本泌尿器科学会総会, 及び1979年10月第21回日本脈管学会において発表した。 なお本研究の一部は厚生省がん研究助成金53-19によっ た.

\section{文献}

1) Almgård, L.E. and Fernström, I.: Embolic occlusion of an intrarenal aneurysm: A case report. Brit. J. Urol., 45, 485—486, 1973.

2) 青木清一: シンポジウム/泌尿器科領域に扰け る動脈閉塞法一動脈閉塞法の臨床評価(再開通, 免疫能の推移など). 臨泌, 33, 1094-1096, 1976.

3) Bergreen, P.W., Woodside, J. and Paster, S.B.: Therapeutic renal infarction. J. Urol, 118, 372-374, 1977.

4) Bookstein, J.J. and Goldstein, H.M.: Successful management of postbiopsy arteriovenous fistula with selective arterial embolization. Radiclogy, 109, 535-536, 1973.

5) Chuang, V.P., Reuter, S.R., Walter, J., Foley, W.D. and Bookstein, J.J.: Control of renal hamorrhage by selective arterial embclization. Am. J. Roentgenol., 125, 300-306, 1975.

6) Goldstein, H.M., Medellin, H., Beydon, M.T., Wallace, S., Ben-Menachem, Y., Bracken, R.B. and Johnson, D.E.: Transcatheter embolization of renal cell carcinoma. Am. J. Roentgenol., 123, 557-562, 1975.

7) Higgins, C.B., Bookstein, J.J., Davis, G.B., Galloway, D.C. and Barr, J.W.: Therapeutic embolization for intractable chronic bleeding. Radiology, 122, 473—478, 1977.

8) 加藤哲郎, 桑原正明, 三浦邦夫, 石川 清, 根 本良介：腎癌に対する術前 Transcatheser Embolization一自験症例の検討 と文献的考察一. 日 泌尿会誌，68，391-397，1977.

9) Lalli, A.F., Peterson, N. and Bookstein, J.J.: Roentgenguided infarction of kidneys and lungs. A potential therapeutic technic. Radiclogy, 93, 434—435, 1969.

10) Lang, E.K.: Superselective arterial catheterization as a vehicle for delivering radioactive infarct particles to tumcrs. Radiology, 98, 391399, 1971.

11) Lang, E.K., Deutsch, J.S., Goodman, J.R., Bernet, T.F., Lanasa, J.A. Jr. and Duplessis, G.H.: Transcatheter embolization of hypogastric branch arteries in the management of intractable bladder hemorrhage. J. Urol., 121, 30-36, 1979.

12）町田豊平, 小路 良, 增田富士男, 三木 誠, 小林睦生, 大石幸彦, 佐々木忠正: 腎癌に対す る transcatheter embolization一第 1 報 栓塞法
の改良一. 日泌尿会誌, 69, 459-464，1978.

13) Margolies, M.N., Ring, E.J., Waltman, A.C., Kerr, W.S. Jr. and Baum, S.: Arteriography in the management of hemorrhage from pelvic fractures. N. Engl. J. Med., 287, 317-321, 1972.

14）松村俊宏，川村正喜，山本啓介，山口哲男，川 喜多順二, 前田 勉, 西尾正一, 早原信行, 中 西純造, 岸本武利, 前川正信, 山田竜作, 水口 和夫, 中塚春樹, 船井勝七, 辻田正昭：腎癌 に対する transcatheter embolization，日泌尿会 誌, 69, 1094-1103, 1978.

15) Miller, F.J. Jr., Motel, R., Mann, W.J. and Jahshan, A.E.: Selective arterial embolization for control of hemorrhage in pelvic malignancy: Femoral and brachial catheter approaches. Am. J. Roentgenol., 126, 10281032, 1976.

16) Mohri, M. and Hiramatsu, K.: Simplified bilateral selective catheterization of the uterine artery. Radiology, 129, 239-241, 1978.

17) Nevin, J.E. and Hoffman, A.A.: Use of arterial infusion of 5-fluorouracil either alone or in combination with supervoltage and radiation as a treatment for carcinoma of the prostate and bladder. Am. J. Surgery, 130, 544-549, 1975.

18) Ogata, J., Migita, N. and Nakayama, T.: Treatment of carcinoma of the bladder by infusion of the anticancer agent (Mitomycin C) via the internal iliac artery. J. Urol., 110, 667-670, 1973.

19) Paster, S.B., Bergreen, P. and Schwarz, H.: Percutaneous catheter-aided infarction of renal tumors: A preliminary report. J. Urol., 114, 351-354, 1975.

20) Ring, E.J., Athanasoulis, C., Waltman, A.C., Margolies, M.N. and Baum, S.: Arteriographic management $\mathrm{cf}$ hemorrhage following pelvic fracture. Radiology, 109, 65-70, 1973.

21) Schuhrke, T.D. and Barr, J.W.: Intractable bladder hemorrhage: Therapeutic angiographic embolization of the hypogastric arteries. J. Urol., 116, 523, 1976.

22）小路 良, 町田豊平, 增田富士男, 佐々木忠正, 陳 瑞昌, 岡崎武二郎, 田代和也：腎癌に対す る Transcatheter Embolization: 第 2 報 血清醭 素活性および Isoenzyme Pattern の変動. 日泌 尿会誌，70，207-217， 1979.

23) Smith, R.B., Machleder, H.I., Rand, R.W., Bentson, J. and Toubas, P.: Preoperative vascular embolization as an adjunct to successful resection of large retroperitoneal hemangiopericytoma. J. Urol., 115, 206-208, 1976. 
24) Wallece, S., Gianturco, C., Anderson, J.H., Goldstein, H.M., Davis, L.J. and Bree, R.L.: Therapeutic vascular occlusion utilizing steel coil technique: Clinical applications. Am. J. Roentgenol., 127, 381—387, 1976.
25) Woodside, J., Schwarz, H. and Bergreen, P.: Peripheral embolization complicating birateral renal infarction with gelfoam. Am. J. Roentgenol., 126, 1033--1034, 1976.

（1980年 5 月 21 日受付） 